\title{
Seasonal Mineral Concentration in Diets of Esophageally Fistulated Steers on Three Range Areas
}

\author{
R.S. KALMBACHER, K.R. LONG, AND F.G. MARTIN
}

\begin{abstract}
Past analyses of Florida range plants have been hand-plucked, whole-plant samples and have been limited to a few major species sampled at a few times during the year. The objective of this study was to determine if mineral concentrations in hand-plucked samples and the boluses of esophageally fistulated steers: changed from summer to winter; changed on different range areas; could be improved by more frequent grazing. Concentration of $P$ and $K$ in diets collected from steers grazing pine-palmetto, transition, and pond areas were not significantly different, but $\mathrm{Ca}, \mathbf{M g}$, and $\mathbf{M n}$ were usually lower on the pond areas. Concentration of $\mathrm{Zn}$ was similar in diets from the 3 areas in summer, but was lower on pine-palmetto and transition areas in winter. Concentration of $\mathrm{Fe}$ in diets was greater on pond areas than on pine-palmetto areas, while transition areas were intermediate. Concentrations of $P, K$, $\mathbf{M g}$, and $\mathrm{Mn}$ in diets of fistulated steers declined from summer to winter. Concentrations of $P, K, F e$, and $Z n$ were not different between pastures regrazed in winter and grazed only in winter. Most hand-plucked forages declined in mineral concentration from summer to winter. Florida range must be supplemented with complete minerals regardless of season, range site grazed, or grazing management.
\end{abstract}

South Florida flatwoods range sites are made-up of three subsites: pine-palmetto (75\%), maidencane (Panicum hemitomon) ponds $(15 \%)$, and their intergrading areas, referred to as transition areas (10\%) (Hilmon 1964). Pine-palmetto area soils are usually sandy Spodosols, and their low organic matter $(<2 \%)$, together with high rainfall ( $>120 \mathrm{~mm}$ annually) result in plants with low mineral concentration. Wiregrass (Aristida stricta) (Hilmon and Lewis 1962, Kirk et al. 1974); chalky bluestem (Andropogon capillipes), lop-sided indiangrass (Sorghastrum secundum) (Lewis 1970), and creeping bluestem (Schizachyrium stoloniferum)(Kalmbacher and Martin 1981) were found to be below the mineral level necessary for dry, pregnant cows. Large portions of Florida range are grazed from October to March, and native forage that has accumulated from the previous growing season is weathered and senescent, which further adds to the deficiency problems. Soils of the ponds are often Histosols or other soils with high organic matter content, which is responsible for higher dry matter yield and crude protein characteristics of maidencane. Pond vegetation, because of better soils, may have greater mineral supplying potential than pine-palmetto areas.

Previous plant-mineral research has been based on hand-

Authors are associate agronomist, Ona Agricultural Research Center, Ona, Fla. 33865, former graduate assistant, Dept. of Agronomy, and associate statistician University of Florida, Gainesville 32611 .

This article is Florida Agr. Exp. Sta. Pap. No. 3676

Manuscript received March 20, 1982. collected whole plant samples from a few species on pine-palmetto areas. However, range pastures and cattle diets are very diverse. One Florida range pasture contained 109 different species, 42 of which were known to have been eaten by esophageally fistulated steers (Kalmbacher et al. 1984). A total of 26 species were eaten on the pine-palmetto area, 13 species on pond areas, and 15 species were eaten on the transition areas. This complex diet mixture and the variation that occurs within a plant (Kalmbacher 1983) make it difficult to characterize range-plant mineral concentration.

Use of esophageally fistulated animals is an accepted practice to estimate crude protein, digestibility, botanical composition, etc., of cattle diets (Van Dyne and Torrell 1964, Vavra et al. 1978, Lesperance et al. 1974). Use of fistulated cattle to predict the concentration of $P$ in forage (Hoehne et al. 1967, Langlands 1966, Mayland and Lesperance 1977); and $\mathrm{Zn}$ (Little 1975, Mayland and Lesperance 1977), is unreliable because of salivary contamination. Smaller increases due to saliva were found for $\mathrm{K}, \mathrm{Mn}$, and $\mathrm{Fe}$ (Little 1975, Mayland and Lesperance 1977), while $\mathrm{Ca}$ and $\mathrm{Mg}$ could be predicted with reasonable error $( \pm 9 \%$ ) (Little 1975).

Objectives of this research were not to predict absolute plant mineral concentration, but to determine if pine-palmetto, maidencane pond, and transition areas were different in their mineral supplying potential by monitoring bolus $\mathrm{P}, \mathrm{K}, \mathrm{Ca}, \mathrm{Mg}, \mathrm{Fe}, \mathrm{Mn}$, and $\mathrm{Zn}$ concentrations. We also wanted to determine if summerwinter grazing improved mineral supplying potential over winter grazing alone.

\section{Materials and Methods}

A 16.2-ha native pasture in good-to-excellent condition was divided into two 8.1 ha pastures, each containing 5.7 ha of pinepalmetto area; $1.6 \mathrm{ha}$ of maidencane pond; and $0.8 \mathrm{ha}$ of transition area. Both the available forage and species selected by cattle on all 3 sites have been described (Kalmbacher et al. 1984).

Major soils on the pine-palmetto areas were Ona and Smyrna fine sands (sandy, siliceous, hyperthermic Typic and Arenic Haplaquods, respectively). Soil on the pond was a Samsula muck (sandy, siliceous, silicdysic, hyperthermic, Terric Medisaprist), and on the transition area, a Basinger fine sand (sandy, siliceous, hyperthermic, spodic Psammaquent). Flatwoods, transition and pond soils are ranked lower to higher, respectively, in fertility primarily because of an increase in soil organic matter content.

Both pastures were burned in January 1980. One pasture was grazed from 16 June to 26 August 1980 (referred to as 'summer pasture'), the re-grazed between 15 January and 18 March 1981 (referred to as 'winter-regrowth-pasture'). The second pasture was grazed between 12 January and 15 March 1981 (referred to as 
'winter-only-pasture').

Four esophageally fistulated, Brahman cross steers $(325 \mathrm{~kg})$ were used on the summer grazed pasture, and 5 steers were used on the winter-only and winter-regrowth pasture. Steers were hazed to a different area on each collection day and allowed to graze only in that area. Screen-bottom collection bags were used to hold the forage ( 1.0 to $1.5 \mathrm{~kg}$ ) selected by steers during a 15 -minute collection period. Collections were made at $0800 \mathrm{hrs}$, every other day in summer ( 35 different days) 1980, when 47 samples were obtained by steers on pine-palmetto area; 37 on pond area and 17 on the transition area. During winter 1981 collections were made with steers alternately on the winter-only, and winter-regrowth-pastures. All areas were grazed on one pasture, then during the next 3 days, all areas were grazed on the other pasture. There were 38 samples collected through steers on the pine-palmetto of the winterregrowth-pasture, 36 samples on its pond, and 37 samples on its transition area ( 24 different days). On the winter-only-pasture there were 36 samples collected on each of the 3 areas over 24 days.

Two nonfistulated steers $(375 \mathrm{~kg})$ were placed on each pasture to assure uniform grazing and provide additional grazing pressure. Stocking rates (includes all cattle) for the summer, winterregrowth, and winter-only-pasture were 55,45 , and 53 animal unit grazing days/ha, respectively. All cattle were given free-choice mineral ${ }^{3}$.

Diet samples collected from fistulated steers were spread on screen trays, dried overnight at $50^{\circ} \mathrm{C}$, ground ( 40 mesh screen), and wet-ashed. Plant $\mathbf{P}$ was determined by the vanadomolybdate method (Jackson 1958), and $\mathrm{K}, \mathrm{Ca}, \mathrm{Mg}, \mathrm{Fe}, \mathrm{Mn}, \mathrm{Zn}$, and $\mathrm{Cu}$ were determined by atomic absorption. Standard reference materials (fruit orchard leaves) from the National Bureau of Standards were used to check analytical accuracy.

Hand-collected samples of major forages consumed by fistulated steers were collected weekly to provide trends on mineral concentration which could be used to compare with concentration in the boluses. Forages were collected on the area where cattle were grazing in each pasture, and the parts collected were similar to those eaten by steers. Hand collected samples were dried at the same temperature and duration, ground, and analyzed for the same minerals as diet samples collected from fistulated steers. All data were presented on an oven-dried $\left(50^{\circ} \mathrm{C}\right)$ basis.

Results from mineral analyses were treated as a sampling problem to describe the effect of range area, season and regrazing through a method of least squares. The general linear model (GLM) of statistical analysis systems (SAS) (Helwig and Council 1979) was used. Replications were the 4 or 5 esophageally fistulated steers.

IOna Station Mineral No. 2 contains: $\mathrm{Ca}, 12 \% ; \mathrm{P}, 12 \% ; \mathrm{NaCl}, 25 \% ; \mathrm{Fe}, 1.0 \% ; \mathrm{Cu}$, $0.13 \% ; \mathrm{Co}, 0.03 \% ; \mathrm{Mn}, 0.05 \% ; \mathrm{Zn}, 0.10 \% ; \mathrm{I}, 0.04 \% ; \mathrm{F}, 0.18 \%$.

\section{Results and Discussion}

\section{Effect of Season and Previous Grazing}

Diets of cattle grazing the summer pasture had higher $(P \leq 0.01)$ $K$ concentrations than diets of cattle grazing winter-only or winterregrowth pastures (Table 1). Concentrations of $P$ in diets were greater $(P \leq 0.01)$ on the summer than the winter-regrowth pasture, but there was no $(P \leq 0.05)$ difference in $P$ concentration in diets from the summer vs winter only pasture. There was no difference in concentrations of $P$ and $K$ when the winter-regrowth and winteronly pastures were compared.

During winter, frost is common in sub-tropical Florida $\left(26^{\circ} \mathrm{N}\right)$, and the winter of 1981 was colder than normal. Mean low was $1.8^{\circ} \mathrm{C}$ vs. $9.5^{\circ} \mathrm{C}$ for the 36-year average (Dantzman and Hodges 1980). Grass was weathered and senescent, and grazing of regrowth from previously grazed summer pasture (3-month-old regrowth) did not enhance $P$ and $K$ concentration over the pasture grazed only in winter (10-month-old forage).

Deficiency of $\mathbf{P}$ has been reported and recognized in Florida (Kirk et al. 1974, Lewis 1974), but deficiency of $K$ has not received much attention. Creeping bluestem (Kalmbacher and Martin 1981) was reported as being deficient in $\mathrm{K}$ for dry-pregnant cows. Fistulated steers in this study received no $K$ in their mineral supplement, yet values for $\mathbf{K}$ from the forage collected from steers in winter were still deficient in K (NRC 1976) (Table 1).

Iron, $\mathrm{Ca}$, and $\mathrm{Zn}$ concentrations (main effect means) were not significantly different in diets eaten on the summer, winter-only, or winter-regrowth pastures (Table 1). However, there were two significant pasture (season) $\mathrm{x}$ area interactions for $\mathrm{Ca}$ (Table 2), which will be discussed. Because main effect means for the pastures were not different, and since cattle graze all 3 areas in the same pastures on commercial ranches, it is expected that seasonal and regrazing effects on diet Ca would be nominal.

Diets from the summer pasture were higher $(P<0.01)$ in $\mathbf{M g}$ concentration than those from the winter-only and winter-regrowthpasture, but there was no significant difference between winterregrowth and the winter-only-pasture (Table 1). A significant pasture (season) $\mathrm{x}$ area interaction was found for $\mathrm{Mg}$ (Table 2), and this will be discussed as an effect of range areas. The concentrations of $\mathrm{Mn}$ in diets were significantly higher $(P<0.05)$ on both summer and winter regrowth pastures when they were compared to the winter-only pasture, but summer and winter regrowth pastures were not different in diet Mn (Table 1).

\section{Effect of Range Areas}

There was no difference in $P$ and $K$ concentration of esophageally fistulated steer diets grazing on the 3 range areas. Phosphorus on the pine-palmetto area averaged $0.26 \%$; the transition area, $0.21 \%$; and the pond $0.20 \%$. Potassium on these respective areas averaged $0.44 \%, 0.43 \%$, and $0.43 \%$.

Steer diets on the summer and winter-only pasture pond areas

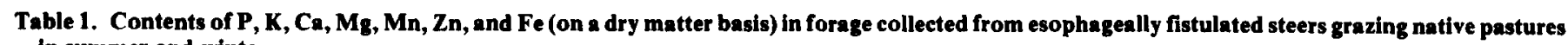
in summer and winter.

\begin{tabular}{|c|c|c|c|c|c|c|c|}
\hline Pasture & $\mathbf{P}$ & $\mathbf{K}$ & $\mathrm{Ca}$ & $\mathbf{M g}$ & $\mathrm{Mn}$ & $\mathrm{Zn}$ & $\mathrm{Fe}$ \\
\hline $\begin{array}{l}\text { Summer } \\
\text { Winter only }\end{array}$ & $\begin{array}{r}0.24 \\
0.21 \\
\text { NS }\end{array}$ & $\begin{array}{c}-1--1- \\
0.68 \\
0.28 \\
* *\end{array}$ & $\begin{array}{c}-\%-1 . \\
0.29 \dagger \\
0.29 \\
\text { NS }\end{array}$ & $\begin{array}{c}0.11 \\
0.08 \\
* *\end{array}$ & $\begin{array}{r}47 \\
40 \\
*\end{array}$ & $\begin{array}{l}21 \dagger \\
22 \\
\text { NS }\end{array}$ & $\begin{array}{l}89 \\
102 \\
\text { NS }\end{array}$ \\
\hline $\begin{array}{l}\text { Summer } \\
\text { Winter regrowth }\end{array}$ & $\begin{array}{c}0.24 \\
0.20 \\
* *\end{array}$ & $\begin{array}{c}0.69 \\
0.34 \\
* *\end{array}$ & $\begin{array}{l}0.29 \dagger \\
0.30 \\
\text { NS }\end{array}$ & $\begin{array}{c}0.11 \\
0.08 \\
* *\end{array}$ & $\begin{array}{l}47 \dagger \\
46 \\
\text { NS }\end{array}$ & $\begin{array}{l}21 \dagger \\
23 \\
\text { NS }\end{array}$ & $\begin{array}{l}89 \\
99 \\
\text { NS }\end{array}$ \\
\hline $\begin{array}{l}\text { Winter only } \\
\text { Winter regrowth }\end{array}$ & $\begin{array}{r}0.21 \\
0.20 \\
\text { NS }\end{array}$ & $\begin{array}{r}0.29 \\
0.34 \\
\text { NS }\end{array}$ & $\begin{array}{l}0.29 \dagger \\
0.30 \\
\text { NS }\end{array}$ & $\begin{array}{c}0.08 \dagger \\
0.08 \\
\text { NS }\end{array}$ & $\begin{array}{l}40 \\
46 \\
* *\end{array}$ & $\begin{array}{l}23 \dagger \\
22 \\
\text { NS }\end{array}$ & $\begin{array}{c}99 \\
102 \\
\text { NS }\end{array}$ \\
\hline
\end{tabular}

\footnotetext{
$\dagger$ Values for this element depend on pasture and/or range site, see accompanying tables.

* for vertical comparison, significant differences $P<0.05$.

** For vertical comparison, significant differences $P<0.01$.

NS not significant.
} 
usually contained less $\mathrm{Ca}$ and $\mathrm{Mg}$ than pine-palmetto and transition areas (Table 2). An increase in diet $\mathrm{Ca}$ and $\mathrm{Mg}$ resulted from regrazing pond areas in the winter, and this resulted in the significant interactions for both $\mathrm{Ca}$ and $\mathrm{Mg}$. Diet $\mathrm{Ca}$ and $\mathrm{Mg}$ from pine-palmetto and transition areas of the winter-only-pasture were higher than $\mathrm{Ca}$ and $\mathrm{Mg}$ in diets from those respective areas on winter-regrowth pasture. Calcium and $\mathrm{Mg}$ concentrations in diets from the pond of the winter-regrowth pasture were higher than concentrations of these elements on the pond of winter-only pasture.

Manganese concentrations in diets tended to be highest on the pine-palmetto area, followed by $\mathrm{Mn}$ in diets from the transition , with the pond area lowest $(P<0.05)$ (Table 2). This was found to be true on the summer pasture and the winter-regrowth-pasture, but the 3 areas on the winter-only-pasture were similar in $\mathrm{Mn}$ concentration.

Concentrations of $\mathrm{Zn}$ in diets from the summer pasture were not different on the 3 areas and averaged $21 \mathrm{ppm}$ (data not in table). On the winter-regrowth and winter-only-pastures, $\mathrm{Zn}$ was usually lower on the pine-palmetto (18 ppm), while pond (26 ppm) and transition areas (24 ppm) were higher (Table 2).

Iron concentrations in diets from the pond tended to be higher than concentrations of $\mathrm{Fe}$ found in diets from other areas, but there were no significant differences. Main effect means for the 3 areas were: pine-palmetto, $90 \mathrm{ppm}$; transition, $96 \mathrm{ppm}$; and pond, 103 ppm.

It was anticipated that the pond area, because of the organic soils, would have had greater mineral-supplying potential, but this

Table 2. Calcium, Magnesium, and Zinc content (on a dry matter basis) of forage collected from esophageally fistulated steers grazing in the winter and summer on three areas. Ona, FL 1980-81]

\begin{tabular}{|c|c|c|c|}
\hline Pasture & Pine-palmetto & $\begin{array}{l}\text { Range area } \\
\text { Transition }\end{array}$ & Pond \\
\hline $\begin{array}{l}\text { Summer \& winter only } \\
\text { average } \dagger\end{array}$ & $0.37 \mathrm{a} \ddagger$ & $\begin{array}{l}-\mathrm{Ca} \%- \\
0.30 \mathrm{~b}\end{array}$ & $0.22 \mathrm{c}$ \\
\hline $\begin{array}{l}\text { Summer } \\
\text { Winter regrowth }\end{array}$ & $\begin{array}{l}0.38 \mathrm{a} \\
0.31 \mathrm{a} \\
\text { NS }\end{array}$ & $\begin{array}{l}0.27 \mathrm{ab} \\
0.26 \mathrm{~b} \\
\mathrm{NS}\end{array}$ & $\begin{array}{l}0.21 \mathrm{~b} \\
0.33 \mathrm{~b} \\
*\end{array}$ \\
\hline $\begin{array}{l}\text { Winter only } \\
\text { Winter regrowth }\end{array}$ & $\begin{array}{l}0.36 \mathrm{a} \\
0.31 \mathrm{a} \\
*\end{array}$ & $\begin{array}{l}0.32 \mathrm{a} \\
0.26 \mathrm{~b}\end{array}$ & $\begin{array}{l}0.22 \mathrm{~b} \\
0.33 \mathrm{~b} \\
*\end{array}$ \\
\hline Summer ${ }^{\dagger}$ & $0.13 \mathrm{a} \ddagger$ & $\begin{array}{c}-\mathrm{Mg} \%- \\
0.12 \mathrm{a}\end{array}$ & $0.08 \mathrm{~b}$ \\
\hline $\begin{array}{l}\text { Winter only } \\
\text { Winter regrowth }\end{array}$ & $\begin{array}{l}0.10 \mathrm{a} \\
0.09 \mathrm{a} \\
*\end{array}$ & $\begin{array}{l}0.09 \mathrm{a} \\
0.08 \mathrm{~b} \\
*\end{array}$ & $\begin{array}{l}0.07 \mathrm{~b} \\
0.09 \mathrm{a} \\
*\end{array}$ \\
\hline $\begin{array}{l}\text { Summer \& winter regrowth } \\
\text { average } \dagger\end{array}$ & 52 af & $\begin{array}{c}-\mathrm{Mn} \text { ppm - } \\
47 \mathrm{a}\end{array}$ & $39 \mathrm{~b}$ \\
\hline $\begin{array}{l}\text { Winter only and } \\
\text { winter regrowth average } \dagger\end{array}$ & $18 \mathrm{bt}$ & $\begin{array}{c}-\mathrm{Zn} \text { ppm - } \\
24 \text { a }\end{array}$ & $26 \mathrm{a}$ \\
\hline
\end{tabular}

† no significant pasture $X$ range area interaction.

$¥$ means on a line followed by the same letter are not significantly different (Duncan's least significant difference test, $P<0.05$ ).

* for vertical comparison, significantly different, $P<0.05$.

NS not significant. was not found to be true. Zinc was the only element that was found in greater concentration in diets collected from steers grazing the pond as compared with $\mathrm{Zn}$ in diets from pine-palmetto and transition areas. Concentration of $P$ and $K$ in diets was similar on the 3 areas, but $\mathrm{Ca}, \mathrm{Mg}$, and $\mathrm{Mn}$ were lower on the pond than on pine-palmetto and transition areas.

Copper concentration was determined in diet samples from fistulated steers, but because of the trace amounts present, we felt that any response due to area or pasture could be masked by salivary contaminations of $\mathrm{Cu}$. Therefore, $\mathrm{Cu}$ concentration of diet samples has not been presented.

\section{Mineral Concentration in Hand-collected Forage}

Mineral concentration in hand-plucked grasses averaged $0.08 \%$ $\mathrm{P}, 0.34 \% \mathrm{~K}$, and $0.10 \% \mathrm{Mg}$ in summer, but declined to $0.05 \% \mathrm{P}$, $0.17 \% \mathrm{~K}$, and $0.07 \% \mathrm{Mg}$ in winter. Average summer and winter concentrations of $\mathrm{Ca}, \mathrm{Mn}, \mathrm{Cu}$, and $\mathrm{Zn}$ were 0.19 and $0.17 \% \mathrm{Ca}, 39$ and $32 \mathrm{ppm} \mathrm{Mn,} 3$ and $3 \mathrm{ppm} \mathrm{Cu}$, and 14 and $15 \mathrm{ppm} \mathrm{Zn}$, respectively. Average $\mathrm{Fe}$ concentration in grasses was $46 \mathrm{ppm}$ in summer and $76 \mathrm{ppm}$ in winter. Kalmbacher and Martin (1981) found that concentrations of $\mathbf{P}, \mathrm{K}$, and $\mathrm{Mg}$ in creeping bluestem were higher $(P \leq 0.05)$ in October before frost when compared with concentrations after frost and weathering in January and February. In the same study Fe concentrations in creeping bluestem increased in January and February. Creeping bluestem and chalky bluestem were two grasses that together made-up more than $40 \%$ of steer diets on pine-palmetto areas in summer and winter (Kalmbacher et al. 1984). A decline in concentration of $P, K$, and $\mathrm{Mg}$ in these plants is indicative of the decline in $\mathrm{P}, \mathrm{K}$, and $\mathrm{Mg}$ that was observed in summer and winter diets (Table 1 ).

Forbs and grass-like plants such as: Carex and Juncus spp, Lacnanthes caroliniana, Polygala spp, Xyris spp and Rhexia spp, averaged $0.09 \% \mathrm{P}, 0.33 \% \mathrm{~K}, 0.46 \% \mathrm{Ca}$, and $0.22 \% \mathrm{Mg}$ in summer. Kalmbacher et al. (1984) found that these plants comprised $20 \%$ of the dry matter of steer diets on pine-palmetto areas and $1 \%$ of the diet from pond areas. Concentrations of minerals in these plants declined in winter to $0.03 \% \mathrm{P}, 0.10 \% \mathrm{~K}, 0.21 \% \mathrm{Ca}$, and $0.08 \% \mathrm{Mg}$. The forbs and grass-likes made up only $6 \%$ of the pine-palmetto area diet in winter, but on pond areas they were found to make-up $47 \%$ of the winter diets (Kalmbacher et al. 1984).

Shrubs like saw palmetto (Serenoa repens) and gallberry (Ilex glabra) were found to make up 6 and $39 \%$ of pine-palmetto area diets in summer and winter, respectively (Kalmbacher et al. 1984). Saw palmetto, which was eaten in both seasons contained $0.11 \% \mathrm{P}$, $0.45 \% \mathrm{~K}, 0.10 \% \mathrm{Ca}$, and $0.12 \% \mathrm{Mg}$ in summer, and $0.08 \% \mathrm{P}, 0.19 \%$ $\mathrm{K}, 0.15 \% \mathrm{Ca}$, and $0.15 \% \mathrm{Mg}$ in winter. Shrubs were less affected by cold than grasses and forbs, and their foliage remained alived through winter.

Comparison of mineral concentrations in forage collected from steers (Table 1) was found to be several times higher than concentrations found in hand-collected forages. This again indicates that forage collected from esophageally fistulated cattle cannot provide absolute estimates of the mineral concentration because of increases from salivary contamination. Since forage was collected from the steers on a day-to-day basis and because cattle were allowed to graze on one area at each collection, trends in the mineral status of the samples should reflect relative differences in the forage that were due to changes in the plant community, soils, or plant maturity.

\section{Conclusions}

Bolus levels of $P$ and $K$ were not different on the 3 range areas, and pond arcas were lower in $\mathrm{Ca}, \mathrm{Mg}$, and $\mathrm{Mn}$. Concentrations of $\mathrm{P}, \mathrm{K}, \mathrm{Mg}$, and $\mathrm{Mn}$ in diets declined from summer to winter ( $\mathrm{Ca}$ and Fe remained the same), while $\mathrm{Zn}$ declined only on the pinepalmetto and transition area. In both summer and winter, hand 
plucked samples were below the levels of all minerals (except Fe and $\mathrm{Mn}$ ) needed for maintenance of dry-pregnant cows (NRC 1976). These data indicate that flatwoods range with soils similar to those of this study need complete mineral supplementation regardless of season, grazing management, or amount of pine-palmetto, pond, and transition areas in the pasture.

\section{Literature Cited}

Dantzman, C.L., and E.M. Hodges. 1980. Weather at Ona, Florida for the 36-year period 1942-1978. Circular S-270. Univ. Florida, Gainesville.

Helwig, J.T., and K.A. Council. 1979. S.A.S. Users Guide. SAS Institute, Raleigh, N.C.

Hilmon, J.B., and C.E. Lewis. 1962. Effect of burning south Florida range. USDA. Forest Serv. Sta. Pap. No. 146, Asheville, N.C.

Hilmon, J.R. 1964. Plants of the Caloosa Fxperimental Range. USDA. Forest Serv. Sta. Pap. No. SE-12. Asheville, N.C.

Hoehne, O.E., D.C. Clanton, and C.L. Streeter. 1967. Chemical changes in esophageal fistula samples caused by salivary contamination and preparation. J. Anim. Sci. 26:628-631.

Jackson, M.L. 1958. Soil Chemical Methods. Prentice-Hall, Inc. Englewood Cliffs, N.J.

Kalmbacher, R.S., and F.G. Martin. 1981. Mineral content in creeping bluestem as affected by time of cutting. J. Range Manage. 34:406-408.

Kalmbacher, R.S., K.R. Long, M. Johnson, F.G. Martin. 1984. Botanical composition of diets of cattle grazing south Florida rangeland. J. Range Managc. (In press).

Kalmbacher, R.S. 1983. Distribution of dry matter and chemical constituents in plant parts of four Florida native grasses. J. Range Manage. 36:298-301.
Kirk, W.G., G.K. Davis, F.G. Martin, E.M. Hodges, and J.F. Easley. 1974. Effect of burning and mowing on the composition of pineland threeawn. J. Range Manage. 27:420-423.

Langlands, J.P. 1966. Studies on the nutritive value of the diet selected by grazing sheep. I. Differences in chemical composition between herbage consumed and material collected from oesophageal fistulae. J. Brit. Soc. Anim. Prod. 8:253-259.

Lesperance, A.L., D.C. Clanton, A.B. Nelson, and C.B. Theurer. 1974. Factors affecting the apparent chemical composition of fistula samples. A publication of Western Regional Coordinating Committee 8, Nevada Agr. Exp. Sta., Reno.

Lewis, C.E. 1970. Response to chopping and phosphate on south Florida range. J. Range Manage. 23:276-282.

Little, D.A. 1975. Studies on cattle with oesophageal fistulae. Comparison of concentration of mineral nutrients in feeds and associated boluses. Australian J. Exp. Agr. Anim. Husb. 15:437-439.

Mayland, H.F., and A.L. Lesperance. 1977. Mineral composition of rumen fistula samples compared to diet. J. Range Manage. 39:338-390.

NRC. 1976. Nutrient requirements of domestic animals. No. 1. Nutrient requirements of beef cattle. Fifth revised ed. Nat. Acad. Sci., Nat. Res. Council. Washington, D.C.

Van Dyne, G.M., and D.R. Torrell. 1964. Development and use of the esophageal fistula: A review. J. Range Manage. 17:7-19.

Vavra, M., R.W. Rice, and R.M. Hansen. 1978. A comparison of esophageal fistula and fecal material to determine steer diets. J. Range Manage. 31:11-13.

\section{POSITION AVAILABLE}

POSITION: Range Animal Nutritionist. Available on June 1, 1984.

RANK: Assistant or associate professor. This position and other similar research positions do not have tenure.

LOCATION: Texas A\&M University Agricultural Research and Extension Center, Vernon, Texas.

MINIMUM QUALIFICATIONS: Ph.D. in Range Science or closely related field with research experience in nutrition of grazing beef animals. Two or more years post-doctorial research experience preferred.

SALARY: Competitive with other States and consistent with experience of candidate.

CLOSING DATE FOR APPLICATIONS: Applications will be received until June 1,1984 or until a suitable candidae is found.

DUTIES AND RESPONSIBILITIES: The scientist will develop a research program which addresses nutritional problems of grazing animals with the primary emphasis on beef animals. It is expected that a significant research program will be developed in cooperation with scientists at the Texas Experimental
Ranch. Opportunities exist to develop research on stockers at the Spur Research Station and on grazing animals with cooperator producers in the Rolling Plains.

FACILITIES: The Vernon Research Center consists of a modern research facility with a staff of 40 including 10 Ph.D. members. A nutrition laboratory and a laboratory technician are available at Vernon. The Texas Experimental Ranch consists of approximately 7,000 acres of native range and is available for research with some constraints on stressing animals. The Spur Research Station consists of 1400 acres of range and cultivated land. Several large ranches in the area provide an opportunity to develop cooperative research programs.

TO APPLY: Send a resume, official transcript, and three letters of recommendation to:

Dr. Earl C. Gilmore, Jr.

Resident Director of Research

Texas A\&M Research and Extension Center

P.O. Box 1658

Vernon, Texas 76384

AN EQUAL OPPORTUNITY EMPLOYER 